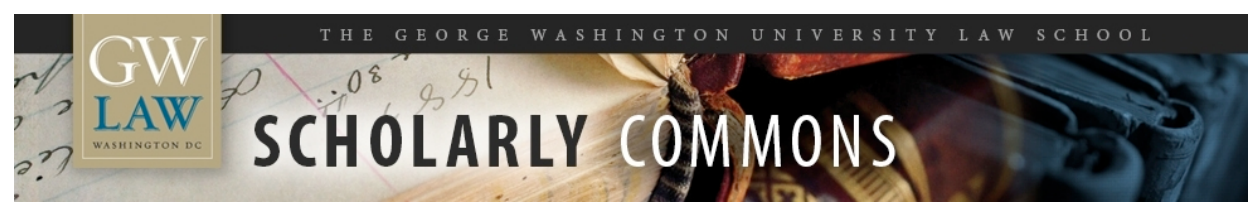

\title{
Comment Letter In Opposition to the OCC's Proposed "Valid- When-Made" Rule
}

Arthur E. Wilmarth Jr.

George Washington University Law School, awilmarth@law.gwu.edu

Follow this and additional works at: https://scholarship.law.gwu.edu/faculty_publications

Part of the Law Commons

\section{Recommended Citation}

Wilmarth, Arthur E. Jr., "Comment Letter In Opposition to the OCC's Proposed "Valid-When-Made" Rule" (2020). GW Law Faculty Publications \& Other Works. 1476.

https://scholarship.law.gwu.edu/faculty_publications/1476

This Article is brought to you for free and open access by the Faculty Scholarship at Scholarly Commons. It has been accepted for inclusion in GW Law Faculty Publications \& Other Works by an authorized administrator of Scholarly Commons. For more information, please contact spagel@law.gwu.edu. 
Arthur E. Wilmarth, Jr.

Professor of Law

George Washington University Law School

2000 H Street, N.W., Room B503

Washington, DC 20052

Email: awilmarth@law.gwu.edu

January 17, 2020

Office of the Comptroller of the Currency

400 - 7th Street, S.W., Suite 3E - 218

Washington, DC 20219

\section{Re: Docket ID OCC-2019-0027: Notice of Proposed Rulemaking - "Permissible Interest on Loans That Are Sold, Assigned, or Otherwise Transferred," 84 Fed. Reg. 64229 (Nov. 21, 2019)}

Thank you for giving the public an opportunity to submit comments on the proposed rule issued by the Office of the Comptroller of the Currency (OCC), which would "codify" the socalled "valid-when-made principle." The proposed rule would amend two of the OCC's regulations governing national banks and federal savings associations - 12 C.F.R. 7.4001 and 12 C.F.R. 160.110 - by providing that "interest on a loan that is permissible under [12 U.S.C.] 85 and $1463(\mathrm{~g})(1)$, respectively, shall not be affected by the sale, assignment, or other transfer of the loan.” 84 Fed. Reg. at 64230-31.

For the following three reasons, the proposed rule exceeds the OCC's authority and is also contrary to the public interest:

(1) The proposed rule does not comply with the procedural and substantive requirements of 12 U.S.C. 25b, which governs rules and orders issued by the OCC that seek to preempt state consumer financial protection laws.

(2) The proposed rule would unlawfully expand the preemptive scope of 12 U.S.C. 85 and $1463(\mathrm{~g})(1)$ beyond the limits established by Congress, without congressional authorization and in contravention of applicable court decisions.

(3) The proposed rule is contrary to the public interest because it would encourage predatory high-cost lending and other abusive practices that would inflict very serious injuries on consumers.

The following discussion explains in detail why the OCC's proposed rule would be unlawful and contrary to the public interest if it were adopted. The OCC should withdraw the proposed rule, and the OCC should not issue any other rule or order that would attempt to 
expand the preemptive scope of 12 U.S.C. 85 and $1463(\mathrm{~g})$ to reach purchasers, assignees, and transferees of loans made by national banks and federal thrifts.

\section{The Proposed Rule Does Not Comply with 12 U.S.C. 25b}

The Dodd-Frank Wall Street Reform and Consumer Protection Act, Pub. L. No. 111-203, 124 Stat. 1376 (2010) (Dodd-Frank), established a new statutory framework to determine the applicability of state consumer financial laws to national banks and federal savings associations. Under 12 U.S.C. $25 \mathrm{~b}(\mathrm{~b})$, a state consumer financial law is preempted "only if" the state law has "a discriminatory effect on national banks" or the state law "prevents or significantly interferes with the exercise by the national bank of its powers." Section 25b(b)(1)(B) expressly incorporates the "prevent or significantly interfere" standard for preemption set forth in Barnett Bank of Marion County, N.A. v. Nelson, 517 U.S. 25, 33 (1996). See Lusnak v. Bank of America, N.A., 883 F.3d 1185, 1188, 1191-94 (9th Cir.), cert. denied, 139 S. Ct. 567 (2018). Under 12 U.S.C. 1465(a), preemption determinations concerning the applicability of state laws to federal savings associations are governed by "the laws and legal standards applicable to national banks regarding the preemption of State law," including Section 25b. Thus, under Dodd-Frank, the same preemption standards control the application of state laws to both national banks and federal thrifts. ${ }^{1}$

Section 25b(b)(4) and Section 1465(b) declare that the National Bank Act (NBA) and the Home Owners' Loan Act (HOLA) do not "occupy the field in any area of state law." Accordingly, field preemption does not exist under either the NBA or HOLA. Instead, a state law is preempted only when it creates an "irreconcilable conflict" with federal law, based on the "prevent or significantly interfere" preemption standard established in Barnett Bank, 517 U.S. at 31, 33; see Elosta, supra note 1, at 1276-77, 1298; Wilmarth, supra note 1, at 927-28, 932.

The OCC's notice of proposed rulemaking makes the erroneous assertion that national banks and federal thrifts can "operate across state lines without being hindered by differing state laws." 84 Fed. Reg. at 64230. On the contrary, the Supreme Court has repeatedly held that national banks "are subject to the laws of the State, and are governed in their daily course of business far more by the laws of the State than of the nation. All their contracts are governed and construed by State laws. Their acquisition and transfer of property, their right to collect their debts, and their liability to be sued for debts, are all based on State law." Atherton v. FDIC, 519 U.S. 213, 222-23 (1997) (quoting National Bank v. Commonwealth, 76 U.S. (9 Wall.) 353, 362 (1870)). In Cuomo v. Clearing House Ass'n, 559 U.S. 519, 534 (2009), the Court explained that "States . . have always enforced their general laws against national banks - and have enforced their banking-related laws against national banks for at least 85 years." See also Lusnak, 883 F.3d at 1191 ("Where, as here, we are confronted with state consumer protection laws, 'a field traditionally regulated by the states, compelling evidence of an intention to preempt is required."') (citations omitted); Wilmarth, supra note 1, at 944-48 (discussing additional Supreme Court decisions upholding the application of state laws to national banks).

\footnotetext{
${ }^{1}$ Jared Elosta, "Dynamic Federalism and Consumer Financial Protection: How the Dodd-Frank Act Changes the Preemption Debate," 89 North Carolina Law Review 1273, 1298 (2011); Arthur E. Wilmarth, Jr., "The Dodd-Frank Act's Expansion of State Authority to Protect Consumers of Financial Services," 36 Journal of Corporation Law 893, 925-28 (2011), available at http://ssrn.com/abstract=1891970.
} 
The OCC's notice of proposed rulemaking does not identify any state usury laws that have "a discriminatory effect on national banks" or federal thrifts. Rather, the OCC's proposed rule is intended to preempt state usury laws that apply equally to federally-chartered and statechartered depository institutions as well as non-depository lenders. Those general state usury laws are unquestionably "state consumer financial laws" under 12 U.S.C. 25b(a)(2).

The OCC's proposed rule would preempt state usury laws from applying to all purchasers, assignees, and other transferees of loans originally made by national banks and federal thrifts. 84 Fed. Reg. at 64231-32. Under 12 U.S.C. $25 b(b)(1)(B)$, the OCC does not have authority to adopt the proposed rule unless it demonstrates that the application of state usury laws to third-party purchasers, assignees, and other transferees "prevents or significantly interferes with" the exercise of an authorized power by national banks and federal thrifts. Lusnak, 883 F.3d at 1191-94; Elosta, supra note 1, at 1298; Wilmarth, supra note 1, at 927-30. The notice of proposed rulemaking does not even attempt to satisfy the "prevents or significantly interferes with" preemption standard.

Under 12 U.S.C. $25 \mathrm{~b}(\mathrm{c})$, the OCC must show that "substantial evidence, made on the record of the proceeding, supports the specific finding regarding the preemption of [state law] in accordance with the legal standard" set forth in Barnett Bank - namely, that the state law in question "prevents or significantly interferes with" the exercise of a lawful power by national banks and federal thrifts. Lusnak, 883 F3d at 1194; Elosta, supra note 1, at 1301; Wilmarth, supra note 1, at 931. The OCC's notice of proposed rulemaking is devoid of any "substantial evidence" showing that application of state usury laws to third-party purchasers, assignees, and transferees "prevents or significantly interferes with" the exercise of an authorized power by national banks and federal thrifts.

The OCC's notice of proposed rulemaking includes only the following general assertions, which are not supported by any factual evidence: (1) a bank's ability to assign a loan "may be unduly curtailed if the bank cannot be certain that interest permissible prior to the assignment will remain permissible afterwards," and (2) a bank's ability to use the "risk management tool" of loan assignments or securitizations "would be significantly weakened if the permissible interest on assigned loans were uncertain or if assignment of the permissible interest were limited only to third parties that would be subject to the same or higher usury caps." 84 Fed. Reg. at 64231.

The foregoing unsupported assertions are directly contradicted by Madden v. Midland Funding, LLC, 786 F.3d 246 (2d Cir. 2015), cert. denied, 136 S. Ct. 2505 (2016). In that case, the Second Circuit held that application of state usury laws to debt collectors that acquire loans from national banks "would not prevent consumer debt sales by national banks to third parties." In addition, [a]lthough it is possible that usury laws might decrease the amount a national bank could charge for its consumer debt in certain states ..., such an effect would not 'significantly interfere' with the exercise of a national bank power." 786 F.3d at 251. The Second Circuit held that extending a national bank's preemptive immunity from state usury laws to third-party debt collectors would be an "overly broad application" of the NBA, as that outcome "would create an 
end-run around usury laws for non-national bank entities that are not acting on behalf of a national bank." Id. at 251-52.

The FDIC has issued a proposed rule that is designed to "maintain parity" for FDICinsured, state-chartered banks and savings associations. The FDIC's proposed rule would give purchasers, assignees, and transferees of loans made by insured state-chartered depository institutions the same preemptive immunity that the OCC proposes to give to contractual counterparties of national banks and federal thrifts. Fed. Deposit Ins. Corp., Notice of proposed rulemaking, "Federal Interest Rate Authority," 84 Fed. Reg. 66845, 66849-50 (Dec. 6, 2019). However, the FDIC's notice of proposed rulemaking states that the FDIC "is not aware of any widespread or significant negative effects on credit availability or securitization markets having occurred to this point as a result of the Madden decision." The FDIC's rulemaking repeats that assessment, stating that the FDIC "is not aware of any broad effects on credit availability having occurred as a result of Madden." Id. at 66850, 66852 (Dec. 6, 2019) (emphasis added). The FDIC's statements, like the Madden decision, demonstrate the absence of "substantial evidence" that would justify the OCC's claim of preemption in the proposed rule.

In addition, the OCC's proposed rule does not comply with the requirement that the OCC must act on a "case-by-case basis" under Section $25 \mathrm{~b}(\mathrm{~b})(1)(\mathrm{B})$ and (b)(3) when it issues a preemptive rule or order. Lusnak, 883 F.3d at 1192, 1194; Elosta, supra note 1, at 1300-01; Wilmarth, supra note 1, at 931. To satisfy the "case-by-case" requirement, the OCC must consider "the impact of a particular State consumer financial law on any national bank that is subject to that law, or the law of any other State with substantially equivalent terms." 12 U.S.C. 25b(b)(3)(A). Thus, the OCC must identify each state usury law that it believes would meet the Barnett Bank preemption standard set forth in Section 25b(b)(1)(B). In addition, the OCC must "first consult with the Bureau of Consumer Financial Protection and take the views of the Bureau into account" when the OCC makes its "case-by-case" determination. 12 U.S.C. 25b(b)(3)(B). The OCC's notice of proposed rulemaking does not indicate that the OCC has consulted with the Bureau, and the rulemaking also does not contain any identification and analysis of particular state usury laws, as required by the "case-by-case" mandate.

Thus, the OCC's proposed rule does not comply with the substantive and procedural requirements of 12 U.S.C. 25 b. The OCC's notice of proposed rulemaking does not even mention those requirements. The rulemaking refers only to Section $25 \mathrm{~b}$ (f), which provides that Section 25 b does not affect "the authority conferred by [12 U.S.C. 85] for the charging of interest by a national bank...." (emphasis added). See 84 Fed. Reg. at 64231 and note 23.

Section $25 b(f)$ does not exempt the OCC's proposed rule from the substantive and procedural requirements of Section $25 \mathrm{~b}$, because the proposed rule does not deal with the "charging of interest by a national bank." Instead, the proposed rule seeks to preempt state usury laws from applying to the charging of interest by nonbank purchasers, assignees, and other transferees of loans from national banks. Accordingly, any attempt by the OCC to adopt the proposed rule in final form would violate multiple provisions of Section $25 \mathrm{~b}$, including the "prevents or significantly interferes with" preemption standard, the "substantial evidence" requirement, and the "case-by-case" mandate. 
Unfortunately, the OCC's proposed rule is not the first time that the OCC has failed to conform its preemptive rulemaking activities to governing legal standards. In 2004, the OCC adopted sweeping regulations that preempted broad categories of state law across the nation and amounted to "de facto field preemption." The OCC's 2004 preemption rules did not comply with the Barnett Bank "prevent or significantly interfere" preemption standard, and the aggressive preemption theory that the OCC used to justify those rules was subsequently overruled by courts and rejected by Congress in the Dodd-Frank Act.

In Cuomo v. Clearing House, the Supreme Court held that the OCC's aggressive preemption theory underlying its 2004 rules "does not comport with" the NBA because the OCC "attempts to do what Congress declined to do: exempt national banks from all state banking laws, or at least state enforcement of those laws." 557 U.S. at 533. In Lusnak, the Ninth Circuit stated, "The OCC's [2004] preemption rule reads more broadly than Barnett Bank's 'prevent or significantly interfere' standard in two respects." 883 F.3d at 1192 n.4. The Ninth Circuit therefore held that the OCC's 2004 preemption standard "did not conform to Barnett Bank" and was entitled to "little, if any, deference." Id. at 1193. Congress specifically rejected the OCC's 2004 preemption rules when it adopted Section 25b. See S. Rep. No. 111-176. at 175 (2010) (explaining that, under the Dodd-Frank Act, "[t]he standard for preempting State consumer financial law would return to what it had been for decades, those recognized by the Supreme Court in Barnett Bank v. Nelson, 517 U.S. 25 (1996) (Barnett), undoing broader standards adopted by rules, orders, and interpretations issued by the OCC in 2004") (emphasis added); see also Elosta, supra note 1, at 1298-1300; Wilmarth, supra note 1, at 936-37; Wilmarth, supra note 2 , at 246-52.

Congress's displeasure with the OCC's aggressive preemption campaign (further described in Part 3 below) resulted in an unusual provision of Dodd-Frank. Under 12 U.S.C. $25 \mathrm{~b}(\mathrm{~b})(5)(\mathrm{A})$, the OCC's preemption rules and orders are not entitled to deference under Chevron U.S.A., Inc. v. Natural Resources Defense Council, Inc., 467 U.S. 837 (1984). Instead, the OCC's preemption rules and orders receive a much lower level of deference under Skidmore v. Swift \& Co., 323 U.S. 134 (1944). "Dodd-Frank's endorsement of Skidmore deference will force the OCC to bear the burden of persuading the courts that its preemption determinations are correct." Wilmarth, supra note 1, at 932-34; see also Lusnak, 883 F.3d at 1192-93 (explaining the importance of Dodd-Frank's stipulation that 'the OCC's preemption determinations are entitled only to Skidmore deference").

The OCC apparently has not learned from its defeats in the courts and Congress. In 2011, the OCC revised its preemption rules, purportedly to bring them into compliance with Dodd-Frank's mandates set forth in 12 U.S.C. 25b and 1465. 76 Fed. Reg. 43549 (July 21, 2011). However, the OCC's revised rules do not adhere to the Barnett Bank "prevent or significantly interfere" preemption standard, despite Congress's express incorporation of that standard in 12 U.S.C. $25 \mathrm{~b}(\mathrm{~b})(1)(\mathrm{B})$. The OCC's 2011 rulemaking asserted - contrary to the explicit mandate of Congress - that "the Dodd-Frank Act does not create a new stand-alone 'prevents or significantly interferes' preemption standard." 76 Fed. Reg. at 43555. Thus, as the

\footnotetext{
${ }^{2}$ Arthur E. Wilmarth, Jr., "The OCC's Preemption Rules Exceed the Agency's Authority and Present a Serious Threat to the Dual Banking System and Consumer Protection," 23 Annual Review of Banking \& Financial Law 225, 228-30, 233-37 (2004), available at http://ssrn.com/abstract=577863; see also Elosta, supra note 1, at 1280-81.
} 
Ninth Circuit explained in Lusnak, "the OCC has largely reaffirmed its previous preemption conclusions without further analysis under the Barnett Bank standard" mandated by Congress. The Ninth Circuit therefore held that the OCC's "conclusions" in its 2011 preemption rules "are entitled to little, if any, deference." 883 F.3d at $1193 .^{3}$

In addition, three of the preemption rules that the OCC issued in 2011 - 12 C.F.R. 7.4007, 7.4008, and 34.4 - assert that broad categories of state laws are preempted across the nation. In adopting those sweeping and categorical claims of preemption, the OCC did not comply with Section 25b's "substantial evidence" and "case-by-case" procedural requirements, described above. See Wilmarth, supra note 3. The OCC argued that it did not need to comply with Section 25b's procedural requirements because those three rules were based on similar rules adopted in 2004. The OCC claimed that its "regulations in effect prior to the effective date [of Dodd-Frank] are not subject to the case-by-case requirement." 76 Fed. Reg. at 43556-57, 43558.

The OCC's assertion that its 2004 rules remained valid - even though they did not comply with Section 25 b's requirements - was plainly erroneous. Under 12 U.S.C.

$25 \mathrm{~b}(\mathrm{~b})(1)(\mathrm{B})$, state consumer financial laws are preempted "only if" a federal agency or court makes a preemption determination in full compliance with all of the requirements of Section 25b. Section 1043 of Dodd-Frank (codified at 12 U.S.C. 5553) made a very limited exception to that mandate. Section 1043 preserved the applicability of existing OCC regulations and orders to "any contract entered into [by a national bank or its subsidiary] before July 21, 2010" (the date of Dodd-Frank's enactment). Congress intended that Section 1043 would "provide stability to existing contracts" - those entered into before Dodd-Frank's enactment - by allowing those contracts to be governed by the OCC's pre-Dodd-Frank rules and orders. S. Rep. No. 111-176, at 175 (2010).

The carefully limited exception in Section 1043 provides compelling evidence of Congress's intent that the OCC's preexisting preemptive rules and orders would not be valid after July 21, 2010, "unless they are brought into full compliance with the new preemption standards and requirements established by [12 U.S.C. 25b]." Wilmarth, supra note 1, at 940. The OCC's argument that its 2004 preemption rules (as reissued in 2011) remained valid for new transactions after 2010 would render Section 1043 "meaningless, in violation of the 'endlessly repeated principle of statutory construction ... that all words in a statute are to be assigned meaning, and that nothing therein is to be construed as surplusage." Independent Insurance Agents of America, Inc. v. Hawke, 211 F.3d 638, 643-44 (2000) (quoting Qi-Zhou v. Meissner, 70 F.3d 136, 139 (D.C. Cir. 1995)). Thus, the OCC violated 12 U.S.C. $25 \mathrm{~b}$ when it adopted three blanket preemption rules in 2011 - 12 C.F.R. 7.4007, 7.4008, and 34.4 - without complying with the "prevents or significantly interferes" preemption standard or with the "caseby-case" and "substantial evidence" procedural requirements. Wilmarth, supra note 3.

The OCC has also failed to comply with 12 U.S.C. $25 \mathrm{~b}$ (d), which requires the OCC to "periodically conduct a review, though notice and public comment, of each determination that a provision of Federal law preempts a State consumer financial law," within five years after

\footnotetext{
${ }^{3}$ See also Arthur E. Wilmarth, Jr., "OCC Gets It Wrong on Preemption, Again,” American Banker (July 29, 2011), at 8, available on Westlaw at 2011 WLNR 14961080 (criticizing the 2011 rules for "refus[ing] to accept "prevents or significantly interferes" as the governing preemption standard for [national] banks").
} 
issuing that determination. The OCC must provide notice of, and invite public comments on, each preemption review. The OCC must also publish a notice describing the results of each review and submit a report to the House Financial Services Committee and the Senate Committee on Banking, Housing, and Urban Affairs. The OCC's published notice and report to those Committees must state whether the OCC intends to continue, rescind, or amend the preemption determination. I am not aware of any public review conducted by the OCC as required by Section $25 \mathrm{~b}(\mathrm{~d})$, even though the OCC issued its most important preemption rules in July 2011, more than eight years ago. The OCC has issued several other preemption rules that are at least 15-20 years old, and to my knowledge it has not conducted any public review of those rules. See, e.g., 12 C.F.R. 7.4002, 7.4003, 7.4004, 7.4005, 34.5, and 37.1.

The OCC cannot "pick and choose what portion of the law binds [it]." First National Bank of Logan v. Walker Bank \& Trust Co., 385 U.S. 252, 261 (1966). The OCC should withdraw the proposed rule due to its glaring lack of compliance with 12 U.S.C. $25 \mathrm{~b}$. The OCC should also conduct public reviews of all of its existing preemption rules and orders that are more than five years old - including those adopted in July 2011 - as required by 12 U.S.C. $25 b(d)$.

\section{The Proposed Rule Would Unlawfully Expand the Preemptive Scope of 12 U.S.C. 85 and 1463(b) Without Congressional Authorization and in Contravention of Applicable Court Decisions.}

\section{a. Sections 85 and 1463 (g) Preempt State Usury Laws Only for "Interest" Lawfully Charged by National Banks and Federal Thrifts}

The OCC does not have authority to expand the scope of preemption under 12 U.S.C. 85 and $1463(\mathrm{~g})$ to reach third-party purchasers, assignees, and transferees of loans made by national banks and federal thrifts. Section 85 specifies the "interest" that a national bank may "take, receive, reserve, and charge" on its loans. The "interest" allowed to a national bank under Section 85 depends on the state or Federal Reserve District in which "the bank is located." Thus, the explicit terms of Section 85 make clear that the power to charge "interest" based on that statute is granted only to national banks and does not extend to purchasers, assignees, or transferees of loans made by national banks. Less than a decade after Congress enacted the NBA, the Supreme Court held that Section 85 was intended "to allow to National associations the rate allowed by the State to natural persons generally, and a higher rate, if State banks of issue were authorized to charge a higher rate." Tiffany v. National Bank of Missouri, 85 U.S. (18 Wall.) 409, 413 (1873) (emphasis added). A century later, the Supreme Court reiterated that Section 85 establishes the terms on which "a national bank may charge interest." Marquette National Bank v. First of Omaha Serv. Corp., 439 U.S. 299, 308 (1978) (emphasis added). The Court pointed out in Marquette that its decision - which allowed a national bank to "export" across state lines the interest rate allowed by the state in which the bank was "located" - did not apply either to the bank's non-depository subsidiary or to other parties with which the bank had contractual relationships. ${ }^{4}$

\footnotetext{
${ }^{4}$ See Marquette, 439 U.S. at 307-08 ("There is no allegation in petitioners' complaints that either Omaha Service Corp. or the Minnesota merchants and banks participating in the BankAmericard program are themselves extending
} 
Under 12 U.S.C. 1463(g)(1), federal savings associations may "charge . . interest" under terms that are "substantially identical" to the authority granted to national banks under Section 85. Garvey Properties/762 v. First Financial Savings \& Loan Ass'n, 845 F.2d 519, 521 (5th Cir. 1988). Congress enacted Section 1463(g) in 1980, in conjunction with 12 U.S.C. 1831d, which provides comparable authority to FDIC-insured, state-chartered banks and savings associations. Congress intended that Sections 1463(g) and 1831d would "provide federally-insured credit institutions with the same 'most-favored-lender' status enjoyed by national banks." Id. In Greenwood Trust Co. v. Massachusetts, 971 F.2d 818, 827 (1st Cir. 1992), cert. denied, 506 U.S. 1052 (1993), the court similarly held that Section 1831d "achieves parity between national banks and their state-chartered counterparts" because Congress made a "conscious choice to incorporate the [National] Bank Act standard" into Section 1831d. Thus, the preemptive immunity granted by Sections 1463(g) and 1831d applies only to "interest" lawfully charged by federally-chartered or federally-insured depository institutions, based on Congress's clearly manifested intent that the parallel preemption provision in Section 85 applies only to "interest" lawfully charged by national banks. See In re Community Bank of N. Va., 418 F.3d 277, 296 (3d Cir. 2005) (12 U.S.C. 85 and 1831d "apply only to national banks and state chartered banks, not to non-bank purchasers of second mortgage loans").

Sections 1463(g) and 1831d were enacted as part of Section 521 of the Depository Institutions Deregulation and Monetary Control Act of 1980, Pub. L. No. 96-221, 94 Stat. 132, 164 (DIDMCA). Congress intended that Section 521 would establish "parity, or competitive equality" between national banks and other federally-chartered or federally-insured depository institutions regarding their authority to charge "interest" on loans. Greenwood Trust, 971 F.2d at 826-27 (quoting 126 Cong. Rec. 6900 (1980) (remarks of Sen. Proxmire)); accord, Garvey, 845 F.2d at 520-22. Sections 1463(g) and 1831d, like Section 85, do not include any reference to the right of a federally-chartered or federally-insured depository institution to transfer its preemptive immunity from state usury laws to purchasers and assignees of its loans.

In contrast, 12 U.S.C. $1735 \mathrm{f}-7 \mathrm{a}$ - enacted as part of Section 501 of DIDMCA - preempts state usury laws from applying to both originations and "credit sales" of first-lien residential mortgages that qualify as "federally related mortgage loans" under 12 U.S.C. 1735f-5(b). In adopting Section 501, Congress expressed a concern with both originations and sales of qualifying first-lien residential mortgages. Congress wanted to "facilitate a national housing policy and the functioning of a national secondary market in mortgage lending." Smith $v$. Fidelity Consumer Discount Co., 898 F.2d 907, 911 (3d Cir. 1990) (quoting S. Rep. No. 96-368, at 19 (1979)). Congress therefore stipulated that qualifying first-lien residential mortgages made by "eligible lenders" would continue to receive the benefit of Section 501's preemption of state usury laws if those mortgages were subsequently sold to investors who were not "eligible lenders." S. Rep. No. 96-368, at 19 (1979) (“[I]t is the committee's intent that loans originated under this usury exemption will not be subject to claims of usury even if they are later sold to an investor who is not exempt under this section.").

credit in violation of Minn.Stat. $§ 48.185$ (1978), and we therefore have no occasion to determine the application of the National Bank Act in such a case."). 
Thus, the preemption authorized by Section 501 of DIMCA expressly applies to sales of first-lien residential mortgages and covers purchasers of those mortgages. In contrast, the preemption authorized by Section 521 of DIDMCA - which was modeled on Section 85 - does not contain any reference to "sales" of loans. The Supreme Court has repeatedly held that Congress is presumed to act "intentionally and purposely" when "it includes particular language in one section of a statute but omits it in another section of the same Act." Barnon v. Sigmon Coal Co.., 534 U.S. 438, 452 (2002) (quoting Russelo v. United States, 464 U.S. 16, 23 (1983)); accord, INS v. Cardoza-Fonseca, 480 U.S. 421, 432 (1987). That presumption is especially strong when the two statues were enacted "simultaneously" by the "same Congress." CardozaFonseca, 480 U.S. at 432. Sections 501 and 521 of DIDMCA were enacted simultaneously in 1980. It must therefore be presumed that Congress acted "intentionally and purposefully" when it did not make any reference to "sales" of loans in Section 521 of DIDMCA, which included both Sections 1463(g) and 1831d.

The strikingly different treatment of "sales" of loans in Sections 501 and 521 of DIDMCA supports the conclusion that the preemption provided by 12 U.S.C. 85 - the historical model for Section 521 - does not extend to purchasers and assignees of loans. See Greenwood Trust, 971 F.2d at 827 ("The historical record clearly requires a court to read the parallel provisions of [DIDMCA] and the [National] Bank Act in pari materia."); accord, In re Community Bank of N. Va., 418 F.3d at 295-96 ("[T] he language of the two statutes [- Sections $1831 \mathrm{~d}$ and $85-$ ] should ordinarily be interpreted in the same way.").

The conclusion that Sections 85, 1463(g), and 1831d do not apply to purchasers and assignees of loans is further bolstered by the Alternative Mortgage Transactions Parity Act, 12 U.S.C. 3801-06 (AMTPA), which was enacted two years after DIDMCA. Under 12 U.S.C. 3803, "housing creditors" (including state-chartered, non-depository lenders) can "make, purchase, and enforce alternative mortgage transactions" in accordance with AMTPA, regardless of contrary state laws. Thus, AMTPA's preemptive scope expressly includes purchasers of qualifying alternative mortgages, in the same way that the preemptive scope of Section 501 of DIDMCA expressly includes purchasers of qualifying first-lien residential mortgages. Section 501 of DIDMCA and AMTPA both demonstrate that Congress knows how to make its intention clear when it wants to provide preemptive immunity for purchasers of loans.

The carefully circumscribed preemption standards in 12 U.S.C. 25 b reinforce the conclusion that Sections 85 and 1463(g) do not provide preemptive immunity for purchasers, assignees, and transferees of loans made by national banks and federal thrifts. Under 12 U.S.C. 25b(b)(2), (e), and (h)(2), state laws apply to subsidiaries, affiliates, and agents of national banks to the same extent as they apply to any other person, corporation, or other entity subject to those state laws - unless the subsidiary, affiliate, or agent is itself chartered as a national bank. See S. Rep. No. 111-176, at 176 (2010) (Under Dodd-Frank, "State law applies to State-chartered nondepository institution subsidiaries, affiliates, and agents of national banks, other than entities that are themselves chartered as national banks."); Wilmarth, supra note 1, at 934-35. State laws also apply to subsidiaries, affiliates, and agents of federal thrifts pursuant to 12 U.S.C. 1465(a).

The foregoing provisions of Section 25b overruled and negated several court decisions issued prior to 2010 - including Watters v. Wachovia Bank, N.A., 550 U.S. 1 (2007) - that 
extended the NBA's preemptive scope to reach subsidiaries and agents of national banks. See Mississippi Dept. of Finance v. Pikco Finance, Inc., 97 So.3d 1203, 1209 n.7 (Miss. 2012); Wilmarth, supra note 1, at 934-35. In light of Congress's decision in Section 25b to deny preemption to subsidiaries, affiliates, and agents of national banks, the OCC's proposed rule would violate Congressional intent by attempting to expand the preemptive scope of Sections 85 and $1463(\mathrm{~g})$ to reach purchasers and assignees of loans. Purchasers and assignees of loans are counterparties to contracts with national banks and federal thrifts, just as agents are and most subsidiaries and affiliates are. Purchasers and assignees of loans therefore cannot claim any entitlement to preemption that Congress has expressly denied to other types of contract counterparties that have closer relationships with national banks and federal thrifts.

As noted above, Section 25b(f) provides additional evidence of Congress's intent not to extend preemption of state usury laws beyond national banks. Section $25 \mathrm{~b}(\mathrm{f})$ preserves only "the authority conferred by section $85 \ldots$ for the charging of interest by a national bank ... (emphasis added). Federal thrifts are subject to the same limited scope of usury preemption under 12 U.S.C. 1465(a).

\section{b. The OCC Has No Authority to Expand the Preemptive Scope of Sections 85 and 1463(g) by Invoking the "Common Law Principle of Valid-When-Made"}

The OCC's notice of proposed rulemaking acknowledges that preemptive immunity for purchasers, assignees, and transferees of loans made by national banks and federal thrifts is "not expressly stated" in Sections 85 and 1463(g). 84 Fed. Reg. at 64230. However, the OCC's rulemaking asserts that the OCC can expand the preemptive scope of Sections 85 and 1463(g) based on "the longstanding common law principle of valid-when-made . . relating to usury." The OCC derives that "common law principle" from two Supreme Court cases decided in the 19th century. Id. at 64231 (citing Nichols v. Fearson, 32 U.S. (7 Pet.) 103 (1833), and Gaither v. Farmers \& Mechanics Bank of Georgetown, 26 U.S. (1 Pet.) 37 (1828).

Professor Adam Levitin has presented a powerful challenge to the accuracy of the OCC's description of the so-called "valid-when-made principle." ${ }^{5}$ Even if one assumes - solely for the sake of argument - that the OCC has correctly described the "valid-when-made principle," the OCC does not have authority to rely on a federal common-law rule from the 19th century to expand the preemptive scope of Sections 85 and 1463(g).

The Supreme Court has made clear since 1938 that " $[\mathrm{t}]$ here is no federal general common law." O’Melveny \& Myers v. FDIC, 512 U.S. 79, 83 (1994) (quoting Erie R. Co. v. Tompkins, 304 U.S. 64, 78 (1938)). The Supreme Court has repeatedly held that "cases in which judicial creation of a special federal [common law] rule would be justified . . . are . . . 'few and restricted." Atherton v. FDIC, 519 U.S. 213, 218 (1997) (quoting O'Melveny \& Myers, 512 U.S. at 87) (quoting Wheeldin v. Wheeler, 373 U.S. 647, 651 (1963)).

\footnotetext{
${ }^{5}$ See Adam Levitin, “Amicus Brief on Valid When Made,” Credit Slips (Sept. 19, 2019), available at https://www.creditslips.org/creditslips/2019/09/amicus-brief-on-valid-when-made.html.
} 
The Supreme Court has rejected two attempts by the FDIC to expand the scope of preemption under federal banking statutes by invoking federal common-law rules. In Atherton, the FDIC cited "federal common-law corporate governance standards" established by 19th century court decisions, which required directors and officers of federally-chartered banks to act with ordinary care (i.e., without negligence). See 519 U.S. 217-18 (citing Briggs v. Spaulding, 141 U.S. 132 (1891), and Martin v. Webb, 110 U.S. 7 (1884)). The FDIC sought to rely on the "federal common law" rule of ordinary care for bank directors and officers to expand the scope of federal preemption of state-law duties of care beyond the limits established in 12 U.S.C. 1821(k). Section 1821(k) imposes liability on directors and officers of FDIC-insured banks for gross negligence - regardless of contrary state law - but it is silent on the question of whether directors and officers of such banks can be held liable for simple negligence. The FDIC claimed that it could impose liability for simple negligence based on the "federal common law" rule established in Briggs, even if applicable state laws denied liability for simple negligence. 519 U.S. at 219-25. Thus, the FDIC's preemption claim in Atherton was precisely the same as the OCC's assertion that it can use "the longstanding common law principle of valid-when-made" to expand the preemptive scope of Sections 85 and 1463(g) to reach purchasers, assignees, and transferees of loans made by national banks and federal thrifts.

The Supreme Court overruled the FDIC's preemption claim in Atherton and held that "state law, not federal common law, provides the applicable rules for decision," except to the extent that state law was expressly preempted by 12 U.S.C. 1821(k). See 519 U.S. at 218, 226. The Court rejected the FDIC's contention that "uniformity" was needed for liability rules applicable to federally-chartered banks. The Court observed that "our Nation's banking system has thrived despite disparities in matters of corporate governance," including "the divergent state-law governance standards applicable to banks chartered in different States." The Court added, "To invoke the concept of "uniformity' . . . is not to prove its need." Id. at 219-21. The Court also rejected the FDIC's argument that a "federal common law standard of care" was justified for all "federally chartered" banks. The Court pointed out that "federally chartered banks are subject to state law," and "a federal charter by itself shows no conflict, threat, or need for "federal common law." Id. at 222-23.

The Court emphasized in Atherton that federal courts will not create or apply a "federal common law" rule absent a compelling need "arising out of a significant conflict or threat to a federal interest." Id. at 224. Thus, "federal common law exists only in such narrow areas as those concerned with the rights and obligations of the United States, interstate and international disputes implicating the conflicting rights of States or our relations with foreign nations, and admiralty courts." Id. at 226 (quoting Texas Industries, Inc. v. Radcliff Materials, Inc., 451 U.S. 630, 641 (1981)). The Court concluded that "federal common-law standards [of ordinary care] enunciated in [19th century] cases such as Briggs did not survive this Court's later decision in Erie v. Tompkins." Id. at 226.

In O'Melveny, the FDIC sued a law firm, alleging that the firm acted negligently and in breach of its fiduciary duties when it represented a failed federally-insured thrift in two real estate syndications. The FDIC relied on a "federal common-law rule" in arguing that the knowledge of corporate officers who breached their fiduciary duties should not be imputed to either the thrift or the FDIC as the thrift's receiver. In contrast, the law of California, where the 
thrift was chartered and located, did impute the knowledge of those officers to both the thrift and the FDIC as receiver. After considering the "comprehensive and detailed" provisions of 12 U.S.C. 1821 - which govern claims by the FDIC as receiver against parties who are allegedly responsible for the failure of a federally-insured depository institution - the Supreme Court held that "matters left unaddressed in such a scheme are presumably left to the disposition provided by state law." Section 1821 is silent regarding imputation of knowledge of corporate officers to their depository institution and to the FDIC as receiver. The Court concluded that Section 1821 "places the FDIC in the shoes of the insolvent S\&L, to work out its claims under state law, except where some provision in the extensive framework of [Section 1821] provides otherwise. To create additional 'federal common-law' exceptions is not to 'supplement' this scheme, but to alter it." 512 U.S. at 85-87 (emphasis added).

The Court also held that the FDIC "identified no significant conflict with an identifiable federal policy or interest. ... The rules of decision at issue here do not govern the primary conduct of the United States or any of its agents or contractors, but affect only the FDIC's rights and liabilities, as receiver, with respect to primary conduct on the part of private actors that has already occurred." 512 U.S. at 88. The Court also rejected the FDIC's argument that a "federal common-law rule" was needed to minimize losses to the FDIC's deposit insurance fund. The Court observed that "there is no federal policy that the fund always win. Our cases have previously rejected 'more money' arguments remarkably similar to the one made here." Id.

The reliance on an alleged "federal common-law rule" in the OCC's proposed rule is untenable and invalid for the same reasons that the Supreme Court rejected the FDIC's efforts to apply similar rules in Atherton and O'Melveny. The OCC's proposed rule, like the rules invoked by the FDIC, applies to transactions involving private parties (national banks and purchasers, assignees, and transferees of their loans). It does not implicate the rights, liabilities, or duties of the United States or its agencies, officials, or contractors, and it also does not involve U.S. foreign relations or admiralty matters. See Atherton, 519 U.S. at 226. The Supreme Court has held that application of a federal common-law rule is not justified when "private parties," including national banks, are involved in a dispute relating to a "private transaction" that "does not touch the rights and duties of the United States." Bank of America Nat'l Trust \& Savings Ass' $n$ v. Parnell, 352 U.S. 29, 33-34 (1956). In another case, the Court refused to create a federal common-law rule that would give federal agencies, as lenders, priority over private creditors (including national banks) in commercial transactions. The Court pointed out that the governing federal statutes for the agencies' lending programs did not expressly preempt the application of state laws governing priority among creditors in commercial transactions. United States v. Kimbell Foods, Inc., 440 U.S. 715 (1979).

In view of the foregoing decisions, the OCC cannot rely on an alleged 19th century federal common-law rule to expand the preemptive scope of 12 U.S.C. 85 and 1463(g) to reach purchasers, assignees, and transferees of loans made by national banks and federal thrifts. The Supreme Court has explained that its refusal to apply federal common-law rules in similar cases reflects the fundamental principle that " [w] hether latent federal power should be exercised to displace state law is primarily a decision for Congress,' not the federal courts." Atherton, 519 U.S. at 218 (quoting Wallis v. Pan American Petroleum Corp., 384 U.S. 63, 68 (1966)). When a party alleges that federal law preempts an area of traditional state regulation, courts "start with 
the assumption that the historic police powers of the States were not to be superseded by the Federal Act unless that was the clear and manifest purpose of Congress." Wyeth v. Levine, 555 U.S. 555, 565 (2009) (quoting Medtronic v. Lohr, 518 U.S. 470, 485 (1996)); accord, Lusnak, 883 F.3d at 1191. "Because consumer protection law is a field traditionally regulated by the states, compelling evidence of an intention to preempt is required in this area." Aguayo v. U.S. Bank, 653 F.3d 912, 917 (9th Cir. 2011) (quoting General Motors Corp. v. Abrams, 897 F.2d 34, 41-42 (2d Cir. 1990)); accord, Lusnak, 883 F.3d at 1191. State usury laws are an exercise of the states' historic police power to protect consumers and other borrowers from predatory interest rates. See Griffith v. Connecticut, 218 U.S. 563, 569 (1910); James M. Ackerman, "Interest Rates and the Law: A History of Usury," 1981 Arizona State Law Journal 61, 85-110 (explaining that state usury laws "are viewed as a protective measure imposed to safeguard consumers from abuse and exploitation by sellers of credit," id. at 110).

There is no "compelling evidence" of any "clear and manifest purpose of Congress" to expand the scope of usury preemption under 12 U.S.C. 85 and $1463(\mathrm{~g})$ to reach purchasers, assignees, and transferees of loans made by national banks and federal thrifts. To the contrary, as shown above, the preemptive terms of Sections 85 and 1463(g) apply only to "interest" that is lawfully charged by national banks and federal thrifts. In contrast, Congress has included broader preemptive language in two statutes - Section 501 of DIDMCA and AMTPA - when Congress wanted to include purchasers of qualifying mortgage loans within the preemptive scope of those statutes.

Accordingly, the OCC should withdraw its proposed rule, and the OCC should not make any further attempts to override state usury laws based on the alleged "valid-when-made" principle.

\section{The OCC's Proposed Rule Is Contrary to the Public Interest}

The OCC's proposed rule is contrary to the public interest because (1) it would encourage high-cost predatory lending that will harm many consumers and small businesses, and (2) it would greatly impair the ability of states to protect their residents from predatory lending. As the National Consumer Law Center (NCLC) recently explained, ${ }^{6}$ the OCC's proposed rule "threatens to eviscerate the ability of states around the country to limit interest rates to protect their residents." By handcuffing the states, the OCC's proposed rule "could encourage 'rent-abank' schemes where payday and other high-cost lenders launder their loans through banks in order to make loans up to $160 \%$ APR in states where those high rates are illegal." NCLC, supra note 6, at 1 (emphasis in original).

"Rent-a-bank" schemes are created by contracts between FDIC-insured banks and highcost nonbank lenders. The typical "rent-a-bank" scheme provides that the bank is the nominal originator of high-cost loans made to consumers or small businesses. However, the nonbank lender markets, reviews, and approves those loans before they are originated by the bank. In addition, the nonbank lender purchases the loans from the bank shortly after origination and

\footnotetext{
${ }^{6}$ National Consumer Law Center (NCLC), "FDIC/OCC Proposal Would Encourage Rent-a-Bank Predatory Lending” (Dec. 2019), available at https://www.nclc.org/images/pdf/high_cost_small_loans/ib-fdic-rent-a-bankproposal-dec2019.pdf.
} 
thereafter services the loans. "Rent-a-bank" schemes are designed to permit high-cost nonbank lenders to evade state usury laws by relying on their partner bank's authority to "export" interest rates from the state in which the bank is "located" to other states. High-cost nonbank lenders therefore partner with banks located in states that have few if any usury limits. In most cases, the bank whose charter is "rented" retains little or no economic risk related to the loans after it sells the loans to the nonbank lender. ${ }^{7}$ See, e.g., In re Community Bank of N. Va., 418 F.3d at 283-84, 294-97 (describing alleged sham "rent-a-bank" arrangements between a predatory nonbank lender and a national bank and an FDIC-insured state bank).

"Rent-a-bank" schemes seek to prevent states from protecting their residents - consumers as well as small business firms - from predatory, high-cost loans that create intolerable risks of delinquency and default for borrowers. The OCC and the FDIC largely shut down "rent-a-bank" schemes in the early 2000s, but those schemes have "ma[de] a comeback" in recent years. The OCC's proposed rule, and the FDIC's similar proposal to adopt 12 C.F.R. 331.4(e), would help "rent-a-bank" schemes to proliferate across the nation, thereby injuring consumers and small businesses by exposing them to predatory and destructive high-cost loans. NCLC, supra note 6 , at 2-6, 8-9; see also Munger, supra note 7, at 482-86.

Several courts have invalidated "rent-a-bank" schemes under the "true lender" doctrine. Under that doctrine, courts have refused to allow nonbank lenders to rely on their partner banks for preemption of state usury laws if the nonbank lenders have the "predominant economic interest" in the relevant loans and are properly viewed as the "true lenders," based on the "totality of the circumstances." When courts conclude that nonbank lenders are the "true lenders," those lenders must comply with applicable state usury laws despite their partnerships with banks. See Munger, supra note 7, at 492-95 (reviewing court decisions applying the "true lender" doctrine).

The OCC has arbitrarily refused to consider the compelling public interest concerns about "rent-a-bank" schemes, as well as the importance of applying the "true lender" doctrine in evaluating such schemes. According to the OCC's notice of proposed rulemaking, "The true lender issue . . . is outside the scope of this rulemaking." 84 Fed. Reg. at 64232 . By refusing to consider the "true lender" doctrine, the OCC will provide great assistance and encouragement to abusive "rent-a-bank" schemes if it adopts the proposed rule. The OCC's proposed rule would allow purchasers, assignees and transferees of loans to charge the same "interest" as the national banks or federal thrifts that originally made those loans. The proposed rule does not contain any exception based on "true lender" considerations. Due to the absence of such an exception, courts faced with future challenges to "rent-a-bank" schemes could possibly determine that the OCC has eliminated the "true lender" issue by regulation. At the very least, courts would be likely to require borrowers to satisfy a substantial burden of persuasion if they tried to raise the "true lender" issue. See NCLC, supra note 6, at 5-6.

Consequently, there is a "clear and present danger" that adoption of the OCC's proposed rule "will lead to an explosion of harmful predatory lending and the evisceration of states'

\footnotetext{
${ }^{7}$ See Jayne Munger, "Note: Crossing State Lines: The Trojan Horse Invasion of Rent-a-Bank and Rent-a-Tribe Schemes in Modern Usury Law," 87 George Washington Law Review 468, 475-77 (2019); NCLC, supra note 6, at 2-4.
} 
historic ability to protect their residents." NCLC, supra note 6, at 9. That dual result - enabling predatory lending and preempting the authority of states to protect their residents - runs directly contrary to Congress's purposes in enacting the Dodd-Frank Act.

When Congress passed the Dodd-Frank Act, it strongly criticized federal financial regulators for failing to take timely and effective actions to stop predatory nonprime mortgage lending during the 1990s and 2000s, even after regulators received many warnings about the dangers of nonprime mortgages. As the Senate committee report explained,

Underlying the whole chain of events leading to the financial crisis was the spectacular failure of the prudential regulators to protect average American homeowners from risky, unaffordable, 'exploding' adjustable-rate mortgages, interest only mortgages, and negative amortization mortgages. These regulators 'routinely sacrificed consumer protection for short-term profitability of banks,' undercapitalized mortgage firms and mortgage brokers, and Wall Street investment firms, despite the fact that so many people were raising the alarm about the problems these loans would cause. ${ }^{8}$

Congress specifically condemned the OCC and the Office of Thrift Supervision (OTS) for aggressively preempting efforts by many states to stop predatory lending during the 1990s and 2000s. Senate Report No. 111-176, at 16-17. The Senate committee report concluded:

In sum, the Federal Reserve and other federal regulators failed to use their authority to deal with mortgage and other consumer abuses in a timely way, and the OCC and the OTS actively created an environment where abusive mortgage lending could flourish without State controls. ${ }^{9}$

In addition, Congress expressed great concerns about abusive financial practices that are directly relevant to the OCC's proposed rule, including manipulative debt collection practices and predatory payday lending. Senate Report No. 111-176, at 19-21. The OCC's proposed rule would severely impair the states' authority to prevent debt collectors and payday lenders from exploiting consumers and small businesses, because the proposed rule would allow debt collectors and payday lenders to evade state usury laws by entering into contracts with national banks and federal thrifts. NCLC, supra note 6, at 2-6, 8-9.

Congress's displeasure with the OTS's and OCC's systematic regulatory failures and unjustified preemption of state laws during the 1990s and 2000s played a major role in Congress's decisions to abolish the OTS and to impose significant constraints on the OCC's authority to preempt state consumer financial laws. Senate Report No. 111-176, at 16-17, 25-26,

\footnotetext{
${ }^{8}$ Senate Report. No. 111-176, at 15 (2010) (quoting testimony of Prof. Patricia McCoy on Mar. 3, 2009). For further analysis of the pervasive failures by federal financial regulators to stop predatory nonprime lending, see Kathleen Engel \& Patricia A. McCoy, The Subprime Virus: Reckless Credit, Regulatory Failure, and Next Steps 157-226 (Oxford University Press, 2011); Wilmarth, supra note 1, at 897-908.

${ }^{9}$ Senate Report No. 111-176, at 17 (2010). For additional discussions of the harms caused to consumers and the U.S. economy by the OCC's and OTS's aggressive preemption of state consumer protection laws and state enforcement efforts, see Elosta, supra note 1, at 1278-81, 1284-86; Engel \& McCoy, supra note 8, at 157-86; Wilmarth, supra note 1, at 909-19; Wilmarth, supra note 2, at 228-37, 306-16, 348-56.
} 
175-77. In light of that history, the OCC should not attempt to launch a new preemption campaign that would undermine the states' historic authority to protect their consumers and small businesses from predatory, high-cost loans (including loans generated by rent-a-bank schemes), as well as abusive collections of such loans by unscrupulous debt collectors.

For all of the reasons stated above, the OCC should withdraw the proposed rule, and the OCC should not issue any other rule or order that would expand the preemptive scope of 12 U.S.C. 85 and $1463(\mathrm{~g})$ to reach purchasers, assignees, and transferees of loans made by national banks and federal thrifts.

**************************************************************

Thank you for your consideration of the foregoing comments.

Very truly yours,

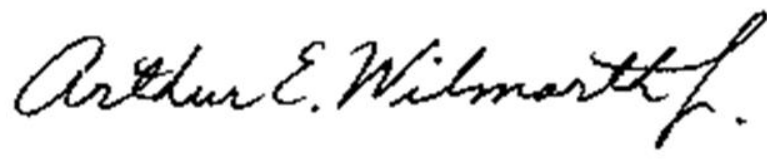

Arthur E. Wilmarth, Jr.

Professor of Law

George Washington University Law School 